\title{
Phenomenology and Experience
}

\author{
New Perspectives
}

Edited by

Antonio Cimino

Cees Leijenhorst

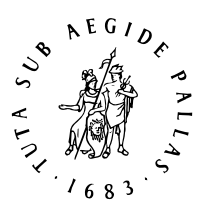

B R I L L

LEIDEN | BOSTON

For use by the Author only | (c) 2019 Koninklijke Brill NV 


\section{Contents}

Acknowledgments VII

Notes on Contributors VIII

Phenomenology and Experience: A Brief Historico-Philosophical

Introduction $\quad 1$

Antonio Cimino and Cees Leijenhorst

What is Diaphenomenology? A Sketch $\quad 12$

Emmanuel Alloa

Transcendental Experience $\quad 28$

Bernardo Ainbinder

Encountering Finitude: On the Hermeneutic Radicalization

of Experience $\quad 46$

Jussi Backman

Poverty and Promise: Towards a Primordial Hermeneutic Experience Gert-Jan van der Heiden

Experience and Unity in Husserl's Solution to the Crisis $\quad 81$

Lorenzo Girardi

Forgetfulness of Experience: Ideality and Necessity in Merleau-Ponty's

Reading of Husserl's "Origin of Geometry" 99

Diego D’Angelo

Conditions of Historical Experience: Husserlian Reflections

114

Timo Miettinen

Motives in Experience: Pfänder, Geiger, and Stein $\quad 129$

Genki Uemura and Alessandro Salice

Experience and Normativity: The Phenomenological Approach $\quad 150$

Sophie Loidolt 
The Specificity of Medium: Painting and Thinking in Merleau-Ponty's "Eye and Mind" $\quad 166$

Nicolas de Warren

Pregnant Embodiment as World Transformation $\quad 185$

Tanja Staehler

Index of Names and Subjects $\quad 201$ 


\title{
Conditions of Historical Experience: Husserlian Reflections
}

\author{
Timo Miettinen
}

We ourselves have developed historically; as historians we ourselves create world history and world science in every sense $[\ldots]$. The world for us is itself a historical structure belonging to us, who are ourselves in our being a historical structure.

EDMUND HUSSERL, The Crisis of the European Sciences and Transcendental Phenomenology 1

Historical experience is a fundamentally modern idea that has referred to at least two competing doctrines. First, historical experience has meant the acknowledgement of the temporal uniqueness of one's own time, the idea that a particular moment - the "just now" (Lat. modo) at the heart of modernityholds a special position in the overall development of human culture. In modern times, this idea was first articulated by Giambattista Vico (1668-1744) whose Scienza nuova (1725) envisioned world history as a recurring, cyclical interplay of different stages: the divine, the heroic, and the human. At the turn of the eighteenth and nineteenth centuries, this cyclical view of history was challenged by several linear accounts, which followed the Augustinian model of world history as proceeding from creation to redemption, from a beginning to an anticipated end. The peculiar uniqueness attributed to the present moment in modern times is a result of this development. Second, historical experience

1 "Wir, die wir universale personale Betrachtung durchführen, in sie universale Betrachtung der Umwelt etc. einbeziehen, sind selbst Menschen, europäische Menschen, sind selbst historisch geworden, wir erzeugen selbst als Historiker Welthistorie und Weltwissenschaft jedes Sinnes, ein historisches Kulturgebilde in der Motivation der europäischen Geschichte, in der wir stehen. Die Welt, die für uns ist, ist selbst ein historisches Gebilde von uns, die wir selbst nach unserem Sein ein historisches Gebilde sind." Edmund Husserl, The Crisis of European Sciences and Transcendental Phenomenology: An Introduction to Phenomenological Philosophy, trans. David Carr (Evanston, IL: Northwestern University Press, 1970), 334 (orig. publ. as Die Krisis der europäischen Wissenschaften und die transzendentale Phänomenologie: Eine Einleitung in die phänomenologische Philosophie, 2nd ed. [The Hague: Nijhoff, 1962], 313). 
has also referred to the idea that the human being itself is a historically developing category. Following Herder and Hegel, it has become common to speak of the historical character of human nature in the sense that what we mean by humanness is defined by different social, cultural, and political conditions and discourses. According to this view, it is the experience or the subject itself that is embedded in history; it is history that provides the key for philosophical understanding of the human being in the first place.

History, of course, is not only a property of the world or the human person. In addition to things that have happened (res gestae), history is also a reflexive activity of the human mind, a conscious representation of what took place (historia rerum gestarum). In this sense, history involves a peculiar relation to past experiences that are transmitted to us through historical evidence such as books, documents, and other portrayals. While history itself is an academic discipline that is a matter of experts and employs a variety of methods, a recognition of the gap between past and present experience is one of the conditions of historical experience as such: we are historical beings because we acknowledge that the experience of past generations is not the same as ours.

From the early nineteenth century onwards, the concept of hermeneutics has been used to describe the growing reflexivity to historical experience in both philosophy as well as individual disciplines. One of the central ideas in the hermeneutical tradition has been that our relation to the past is never a matter of pure description but involves an interpretative element between the whole and its parts. A particular text, for instance, cannot be understood without reflecting the overall context (or the "world") in which it has emerged. Within phenomenological scholarship, this premise has contributed to a wider understanding of experience itself: experience-understood as that medium through which the world is given to us - cannot be understood with such traditional concepts as sensation and reflection, but it involves a relation to a pregiven horizon of meaning.

Husserl called this horizon with the concept of life-world. Especially in his later works, the life-world gained a prominent position as one of the guiding themes of phenomenology in general. Particularly in The Crisis of the European Sciences and Transcendental Phenomenology and its manuscripts, the lifeworld was introduced as a novel "path" to transcendental phenomenology that was to accommodate within itself also the genetic or "generative" dimensions of meaning. ${ }^{2}$ Although Husserl never gave up on the epistemological primacy of the first-person perspective, he began to acknowledge that not all forms

2 Husserl, The Crisis of European Sciences, 103ff. (Die Krisis der europäischen Wissenschaften, $105 \mathrm{ff}$.). 
of experience can be understood on the basis of simple givenness. What we mean by the human person is inseparable from the fact that we are born into a world, which has existed before us and which sets several provisions for our existence. Historical experience, understood in this phenomenological sense, is not merely an accomplishment of a historian but rather the way in which we fasten ourselves to the historical world. As Hans-Georg Gadamer succinctly put it in Truth and Method: "In fact history does not belong to us but rather we to it. [...] The self-awareness of the individual is only a flickering in the closed circuit of historical life." 3

This article addresses the idea of historical experience in Husserl's phenomenology. It addresses three basic conditions for historical experience on the basis of Husserl's later writings: teleology, communality, and finitude. With teleology, I refer to the temporally structured and unified character of human experience. What was unique about Husserl's own approach was not only what Bergson called the "duration" of human experience but rather an idea of unity through disruption. The "inner historicity" of human experience was not to be understood solely as a process of accumulation of meaning but rather as a process of instituting and eliminating, of remembering and forgetting. Communality, in its turn, refers to the basic idea that without a membership in a human community, all talk about historical consciousness seems unfounded. History is, moreover, one of the central practices through which we participate in communal life. Lastly, I will discuss the idea of finitude as one of the key conditions for historical experience. It was exactly the idea of finitude that enabled Husserl to develop a phenomenological theory of generativity, which outlined an understanding of the ways we participate in the culturally and socially defined course of generations.

\section{Teleology}

Although Husserl's earliest analyses on time-consciousness date back to the early 190os, it was not until the 1920s that Husserl started conceptualizing the temporal permanence of the human person and the world. This transition was linked to the idea of genetic phenomenology and the genetic method,

3 "In Wahrheit gehört die Geschichte nicht uns, sondern wir gehören ihr. [...] Die Selbstbesinnung des Individuums ist nur ein Flackern im geschlossenen Stromkreis des geschichtlichen Lebens." Hans-Georg Gadamer, Truth and Method, trans. Joel Weinsheimer and Donald G. Marshall (London: Sheed and Ward, 1988), 245 (orig. publ. as Wahrheit und Methode: Grundzüge einer Philosophischen Hermeneutik, 2nd ed. [Tübingen: Mohr, 1965], 289). 
which were to focus on the dynamic and evolving character of experience and meaning-constitution. ${ }^{4}$ Husserl presented the genetic method as complimentary to the so-called "static" approach, which analyzed the form and content of different acts and modes of consciousness. ${ }^{5}$ In addition to the analysis of types of acts (e.g., predicative, axiological, and practical) and their respective modes of intuitive fulfillment, Husserl presented "a universal theory of genesis" that investigated these acts and structures in regard to their origin and the process or origination. ${ }^{6}$

Husserl spoke of genetic analyses as "explanatory" (erklärende) and distinct from the "descriptive" (beschreibende) analyses of static phenomenology. Instead of describing the nature of the acts themselves, the genetic approach focused on questions of why and how: Why are there certain forms of experience? How are they possible? ${ }^{7}$ This form of explanation was not interested in empirical causality but in what Husserl called relations of motivation, that is, those founding relations that make possible the emergence of different attitudes. ${ }^{8}$ Husserl wanted to understand how exactly different types of acts make each other possible and how particular experiences and instituted meanings acquire a temporally lasting character for themselves.

Husserl called the general form of this set of relations by the concept of "teleology" (Teleologie). ${ }^{9}$ Introduced as a part of the static analyses of

4 Edmund Husserl, Analyses Concerning Passive and Active Synthesis: Lectures on Transcendental Logic, trans. Anthony J. Steinbock, Collected Works, vol. 9 (Dordrecht: Kluwer, 2001), 624ff. (orig. publ. as Analysen zur passiven Synthesis: Aus Vorlesungs- und Forschungmanuskripten 1918-1926 [The Hague: Nijhoff, 1966], 336ff.).

5 Edmund Husserl, Zur Phänomenologie der Intersubjektivität: Texte aus dem Nachlass, 2. Teil: 1921-1928 (The Hague: Nijhoff, 1973), 34-43. See also Edmund Husserl, Zur Phänomenologie der Intersubjektivität: Texte aus dem Nachlass, 3. Teil: 1929-1935 (The Hague: Nijhoff, 1973), $613 \mathrm{ff}$. On the relation between static and genetic phenomenology, see especially Ichiro Yamaguchi, Passive Synthesis und Intersubjektivität bei Edmund Husserl (The Hague: Nijhoff, 1982), 11-14; Donn Welton. The Other Husserl: The Horizons of Transcendental Phenomenology (Bloomington, IN: Indiana University Press, 2000), 1-10, 221ff.

6 Husserl, Analyses Concerning Passive and Active Synthesis, 628ff. (Analysen zur passiven Synthesis, 340ff).

7 Husserl, Analyses Concerning Passive and Active Synthesis, 628-629 (Analysen zur passiven Synthesis, 340). See also Anthony Steinbock, "Husserl's Static and Genetic Phenomenology: Translator's Introduction to Two Essays. Essay 1: Static and Genetic Phenomenological Method," Continental Philosophy Review 31, no. 2 (1998): 128.

8 Edmund Husserl, Cartesian Meditations: An Introduction to Phenomenology, trans. Dorion Cairns (Dordrecht: Kluwer Academic Publishers, 1997), 75 (orig. publ. as Cartesianische Meditationen und Pariser Vorträge [The Hague: Nijhoff, 1950], 109).

9 Husserl, Analyses Concerning Passive and Active Synthesis, 627-628 (Analysen zur passiven Synthesis, 339). 
consciousness, teleology referred to the basic associative or synthetic structure of conscious life, which constitutes the basic unity of experience. To say that our conscious life is "teleologically oriented" simply means that we do not live through mere fleeting experiences, but our conscious life aims at creating concrete beings as unities. For instance, individual perceptions of particular "sides" of a thing have their telos in the constitution of "complete" objects. ${ }^{10}$ Instead of a separate category of being, teleology was to be understood as the "form of all forms" (Form aller Formen), that is, as the general structure of all meaning-constitution that we are constantly living through. ${ }^{11}$ The human person is "teleological through and through", which means that it always embodies a certain constitutive history that delineates a horizon of possibilities for further development. ${ }^{12}$

Husserl understood teleology as being structured by acts of institution (Stiftung). Although the concept referred to the positing of a particular validity or sense, it was practically absent from static analyses of constitution. ${ }^{13}$ Although this notion was very close to what Husserl called "positing" (Setzung) or "thesis" (Thesis) in the first volume of Ideas, it differed from these by focusing on the temporal aspect of meaning-institution. The notion of Stiftung denotes the abiding character of a particular affect, act, or meaning-content, and as such, it opened up the problematic of the temporal genesis of sense. The notion of Stiftung also introduces a whole family of notions (Urstiftung, Nachstiftung, Neustiftung, and Umstiftung), which refer to the dynamic transformation of meaning-institution, its development both in the conscious life of an individual as well as in the field of cultural accomplishments.

10 Husserl, Cartesianische Meditationen und Pariser Vorträge, 12-13; Edmund Husserl, Ideas Pertaining to a Pure Phenomenology and to a Phenomenological Philosophy. First Book: General Introduction to a Pure Phenomenology (Dordrecht: Kluwer Academic Publishers, 1983), 248-249 (orig. publ. as Ideen zu einer reinen Phänomenologie und phänomenologischen Philosophie [The Hague: Nijhoff, 1976], 213).

11 Husserl, Zur Phänomenologie der Intersubjektivität 3. Teil, 380.

12 Edmund Husserl. Phänomenologische Psychologie: Vorlesungen Sommersemester 1925 (The Hague: Nijhoff, 1962), 254 .

13 "Und so ist es also Gesetz: daß jede 'Meinung' eine Stiftung ist [...]" (Edmund Husserl, Ideas Pertaining to a Pure Phenomenology and to a Phenomenological Philosophy. Second Book: Studies in the Phenomenology of Constitution [Dordrecht: Kluwer Academic Publishers, 1989]), 120 (orig. publ. as Ideen zu einer reinen Phänomenologie und phänomenologischen Philosophie. 2. Buch: Phänomenologische Untersuchungen zur Konstitution, Husserliana, vol. 4 [The Hague: Nijhoff, 1952], 113); "So lebe ich in einem Milieu immerfort sich aneinander fügender, sich immer neu ergänzender In-Geltung-Setzung (Stiftung einer Seinsgültigkeit für mich, oder, in der geraden Blickrichtung auf das Gegenständliche, Stiftung für mich „daseiender” Erfahrungsgegenstände)” (Husserl, Phänomenologische Psychologie, 462-463). 
The notion of Urstiftung, "original institution,"14 was the most common formulation that Husserl employed while speaking of meaning-constitution in genetic terms. With this notion, Husserl simply meant the constitution of sense that takes place for the first time-for instance, as in Husserl's own example of familiarizing with a previously unknown object-that creates a lasting validity and a horizon of expectation for future experience. ${ }^{15}$ After this kind of institution, I do not necessarily have to renew this act, but the institution of sense remains an "abiding possession."16 Of course, the original sense that we have bestowed on an object or an event does not necessarily stay the same. As this happens, the original institution undergoes what Husserl calls Nachstiftung or Neustiftung, "re-establishment" or "novel establishment," that is, a transformation of sense that carries the former meaning with it. ${ }^{17}$

Husserl called this accumulation of sense "sedimentation" (Sedimentierung). ${ }^{18}$ The concept referred to the layered character of the temporal development of sense and meaning whereby individual "institutions" or "establishments" follow and ground each other. What was characteristic of this process was a peculiar lack of transparency: although our convictions or

14 See, e.g., Husserl, Cartesian Meditations, 85, 113-117 (Cartesianische Meditationen, 118, 143146); Husserl, Ideas Pertaining to a Pure Phenomenology 2. Book, 124 (Ideen zu einer reinen Phänomenologie, 117); Husserl, Analyses Concerning Passive and Active Synthesis, 254-258 (Analysen zur passiven Synthesis, 203-207); Edmund Husserl. Die Lebenswelt. Auslegungen der Vorgegebenen Welt und ihrer Konstitution: Texte aus dem Nachlass (1916-1937) (Dordrecht: Springer, 2008), 1-6. Urstiftung as a generative notion, see Husserl, The Crisis of European Sciences, 12-13, 71-72 (Die Krisis der europäischen Wissenschaften, 10-11, 72-73); Edmund Husserl, Erste Philosophie (1923/24). 2. Teil: Theorie der phänomenologischen Reduktion (The Hague: Nijhoff, 1959), 17ff.; Die Krisis der europäischen Wissenschaften und die transzendentale Phänomenologie, Ergänzungsbd. Texte aus dem Nachlass 1934-1937 (Dordrecht: Kluwer, 1993), 15ff. At times, Husserl makes a distinction between an "absolute" and a "relative" Urstiftung — the first denoting the creation of a completely novel type of meaning, while the latter stands for a inception which is more or less conformed with an existing framework of sense (Husserl, Die Krisis der europäischen Wissenschaften, Ergänzungsbd., 421).

15 See Husserl, Cartesian Meditations, 111 (Cartesianische Meditationen, 141).

16 Husserl, Cartesian Meditations, 59-6o (Cartesianische Meditationen, 95). "Aber jeder Akt, 'erstmalig' vollzogen, ist 'Urstiftung' einer bleibenden Eigenheit, in die immanente Zeit hinein dauernd (im Sinne eines dauernden Identischen)" (Husserl, Ideas Pertaining to a Pure Phenomenology 2. Book, 324-325 [Ideen zu einer reinen Phänomenologie, 311]).

17 See esp. Husserl, Phänomenologische Psychologie, 212-215. Cf. Husserl, Die Krisis der europäischen Wissenschaften, Ergänzungsbd., 417.

18 See esp. Husserl, Die Krisis der europäischen Wissenschaften, 371ff. Cf. Husserl, Analyses Concerning Passive and Active Synthesis, 22gff. (Analysen zur passiven Synthesis, 180ff.); Husserl, Erste Philosophie 2. Teil, 22ff.; "sedimentation of sense," Sinnsedimentierung (Husserl, Die Krisis der europäischen Wissenschaften, 380). 
practices are often founded on more original institutions of meaning, these founding institutions may be forgotten or remain completely unreflected. Take for instance scientific theories: the development of a new theory, a concept, or a hypothesis often presupposes that we set aside many of the foundational questions characteristic of a particular discipline. When developing his laws of motion, Newton presupposed the Galilean understanding of space as a homogenous and uniform vacuum where no single point occupies a privileged position in regard to others. In classical economics, economic growth is often seen as a synonym for increased well-being and prosperity.

There is understandably nothing wrong with this as such. The tendency to forget merely indicates that the temporal development of meaning and sense is not one of simple accumulation, but rather a complex process of activation and de-activation, of forgetting and remembering. As Husserl himself put it: "Inherited tradition (Erbschaft) is not repetition, but intentional agreement, conversion, concealment, and even transformation through this concealment."19 Thus, in most cases, traditions are born out of an explicit or implicit consensus of what the past is about. In other cases, the fact that certain historical events are forgotten make it possible for a community to keep on existing.

For historical experience in general, the sedimented character of meaning provides several provisions. As I would argue, it is exactly this lack of transparency with regard to the tradition that constitutes one of the central features of historical experience. To experience my situation as historically unique is to recognize not only its dependence from events that took place, but also the fact that these origins are not completely evident. Historical experience is thus essentially a recognition of the past, but one that also acknowledges a certain distance from it: I can only really speak on the basis of my own historical situation in the sense that it is the only situation to which I have a genuine experiential access. Phenomenologically speaking, the non-givenness of the past and the recognition of this non-givenness is what constitutes the uniqueness of historical experience.

Speaking from this point of view, it can be argued that attempts to overcome this lack of transparency have played a significant role in modern philosophies of history. Although it is undeniable that most of what happens remains undocumented and beyond our grasp, history nevertheless embodies a deeper structure and a more profound sense that can be uncovered with the help of philosophical reflection. From the nineteenth century onwards, German

19 "Aber Erbschaft ist nicht Wiederholung, sondern intentionale Einigung, Wandlung, Verdeckung und eben Wandlung durch diese Verdeckung" (Husserl, Erste Philosophie 2. Teil, 436). 
philosophy approached this distinction with the help of two concepts: Historie vs. Geschichte. Whereas Historie referred to the factual side of historical events, it was Geschichte that was to provide a theoretical framework for a purposeoriented understanding of history. As Kant put it in his essay on the idea of universal history, while it is difficult to assume any kind of shared purpose in the "senseless course of human events," the philosopher must set out to find "a history with a definite natural plan for creatures who have no plan of their own." ${ }^{20}$ What Kant and Hegel understood with the concept of teleology was exactly this idea of a hidden purposefulness that characterizes the unfolding of history. "The only thought that philosophy brings with it," Hegel wrote in his lectures on world history, "is the simple thought of reason, that reason rules the world, and that world history has therefore been rational in its course." ${ }^{21}$

In Husserl's view, however, all talk about teleology without reference to the experience itself is fundamentally unfounded. From a phenomenological standpoint, teleology is nothing other than the inherent structure of becoming that characterizes the temporal development of sense and meaning. Thus history, according to Husserl, is "nothing else than the vital movement of the co-existence and the interweaving of original formations and sedimentations of meaning." 22 This development is rational to the extent that it forms a continuum of ideas that are grounded on previous ideas-not because it would comply with a particular pre-established narrative of how things ought to be.

What Husserl called the "teleological-historical reflections" in his later works was essentially nothing other than a coming to grips with this historical embeddedness of experience and the present moment. The basic aim of this reflection or "questioning-back" (rückfragen) was not justification but liberation: it is only by understanding the historical uniqueness of our experienceand the presuppositions governing it - that we are able to resist the idea that thinking itself would be a mere product of its times.

20 " $[A]$ us welcher von Geschöpfen, die ohne eigenen Plan verfahren, dennoch eine Geschichte nach einem bestimmten Plane der Natur möglich sei." Immanuel Kant, Kant's Political Writings, ed. Hans Reiss (Cambridge: Cambridge University Press, 1991), 42, translation modified (orig. publ. as Gesammelte Schriften, Akademie-Ausgabe, vol. 8 [Berlin: Karsten Worm, 1998], 18).

21 G.W.F. Hegel, Vorlesungen über die Philosophie der Geschichte, Theorie Werkausgabe, vol. 12, ed. Eva Moldenhauer and Karl Michel (Frankfurt am Main: Suhrkamp, 1970), 20-21.

22 "Geschichte ist von vornherein nichts anderes als die lebendige Bewegung des Miteinander und Ineinander von ursprünglicher Sinnbildung und Sinnsedimentierung” (Husserl, Die Krisis der europäischen Wissenschaften, 380). 
Ideas of community and history are fundamentally intertwined. Although we sometimes speak of individual histories of particular persons, this sense seems to be a derivation from the more typical use of the concept of history as that of individual communities and cultures, their accomplishments, practices, and ways of life. In this regard, historical experience is closely tied to being with others. To belong to a particular community often means the sharing of a common past, whether it is a family lineage, a common environment or a shared cultural heritage. This is not to say that this past would be uncontested: particularly in contemporary societies, the disputes concerning competing historical narratives and the diverging micro-histories of individual communities are at the heart of social and political debates.

Husserl's own phenomenology of communities was based on his understanding of intersubjectivity as one of the defining features of human existence. This line of investigation-sometimes also called the phenomenology of "socialities" (Sozialitäten) ${ }^{23}$ — was based on Husserl's basic perception on the two-sided character of these relations: unlike other forms of intentionality, intersubjective relations embody within themselves a specific sense of reciprocity through which the social objectivities acquire their unique objectivity. Already in Husserl's early manuscripts, this approach was developed into a theory on the specific social "functions" entailing an intrinsic practical relevance: my relation towards the others is fundamentally characterized by different kinds of responsibilities and practical anticipations that are fundamentally different than in the case of nature or cultural objects. ${ }^{24}$ Social relations, besides that they contain elements that are characteristic of all experience (e.g., seeing, listening), are characterized by uniquely interpersonal experiences such as friendship, love, and persuasion — but also the use of power and violence.

Thus, the being-together of a community depends on intentional acts. As Husserl put it, the unity of a community does not rest upon the "similarity of manners, forms of personal dealings, ways of thinking, opinions, scientific activity, etc." but on "persons who stand within a unity of a spiritual communion

23 As Husserl puts it in C-manuscripts, for the constitution of "socialities," the community of empathy is like what "the spatial form is for reduced nature," that is, the "social space" which allows the temporal simultaneity and succession of individual subjects. See Husserl, Erste Philosophie 2. Teil, 317 .

24 Edmund Husserl, Zur Phänomenologie der Intersubjektivität: Texte aus dem Nachlass, 1. Teil: 1905-1920 (The Hague: Nijhoff, 1973), 104. 
of action." ${ }^{25}$ This unity is essentially a temporal one: it is built on a series of reciprocal acts on the basis of which individual subjects commit themselves to the same cultural world. As Husserl put it in one of his late texts, the whole cultural world is essentially tradition - a "passing forward" of different accomplishments in the course of worldly time - that is given to certain subjects at a certain period of time as an essentially incomplete formation. ${ }^{26}$

This incompleteness becomes manifest, first of all, on the level of givenness: tradition provides us with meanings that are at least partially empty and call for their reactivation in lively intuition. Further, they are also incomplete in another sense, namely, as goals that point towards their future development. To put it more succinctly, culture is essentially inheritance: it appoints its subject as an heir, as someone who is requested or obliged to carry on certain accomplishments, practices, values and so on.

Husserl analyzed these problems under the rubric of generativity (Generativität). ${ }^{27}$ With generativity, Husserl basically denoted the temporal modes of meaning-constitution that take place in the interpersonal and intergenerational forms of co-existence-in different associations, communities, cultures and all kinds of traditions. In this regard, the domain of generativity denoted nothing less than the "unity of historical development in its widest sense"28 — namely, those structures of genetic development that constitute the unified character of traditionality and historicity in general. Against the Hegelian idea of universal history proceeding through the development of spirit, Husserl did not conceive generativity primarily as a universal, formal principle of historical development. Instead, as in the case of individual consciousness, generativity was to be approached through its particular instantiations in individual traditions. As human subjects, we are constantly participating in several generative traditions, which, despite their variations (e.g., family, nation, civilization), all share the general structure of descending and evolving, that is, they are all something passed forward.

25 "Gemeinschaft besagt nicht Gleichheit von Arten, Formen personaler Handlungen, von Denkweisen, Meinungen, wissenschaftlichen Betätigungen etc., sondern in Gemeinschaft stehen Personen, die in solcher Hinsicht in der Einheit eines geistigen Wirkungszusammenhanges stehen, mag im einzelnen die Wirkung überall sichtlich werden oder nicht" (Husserl, Zur Phänomenologie der Intersubjektivität 2. Teil, 183).

26 "Die gesamte Kulturwelt ist nach allen ihren Gestalten aus Tradition da" (Husserl, Die Krisis der europäischen Wissenschaften, 366).

27 On the idea of generativity, see Introduction. Before introducing the notion of generativity, Husserl occasionally referred to problems of "communal genesis" (Gemeinschaftsgenesis), see Husserl, Zur Phänomenologie der Intersubjektivität 2. Teil, 221.

28 Husserl, Die Krisis der europäischen Wissenschaften, Ergänzungsbd., 63. 
What does this mean for historical experience? From a phenomenological perspective, the experience of history is more than an awareness of time. It presupposes an awareness of the continuity of the human person and of the persistence of the world itself. History is always a story of a particular human community located in space and time, a story that concerns both the process as well as the milieu of originating. The history of France, for instance, is both the narrative of the becoming of the French people-its lineages, rulers, and so on-as well as an account of the historical transformation of the landscape: cities, villages, roads, human-made monuments and natural formations. Historical experience-understood as the recognition of the uniqueness of one's own time-is thus essentially linked to the social, cultural, and geographical provisions of this community. In short, it is a phenomenon that concerns the "phenomenological correlation" between the subject and the world.

Husserl employed the concept of the life-world to describe the communally and historically defined correlate of experience. In its "horizonal character," the life-world does not denote a specific intentional correlate of consciousness; rather, it functions as the necessary background of sense through which individual things acquire their meaningful character. As such, the life-world is "constantly pre-given, and constantly valid in advance" 29 - the life-world is what structures our experiential field by offering a comprehensive pre-view of the surrounding world. It is for the sake of life-world that individual things, objects, events and practices have their "default value," that is, they are always projected with regard to a certain idea of expectancy and normality, of familiarity and routine. ${ }^{30}$

With the help of the concept of the life-world, Husserl wanted to refute the idea according to which historical experience would reside merely in the acceptance or construction of a common narrative. Although stories and myths may have a special role in strengthening the sense of unity within different social bodies, these narratives have their foundation in the idea of common world that functions as the indispensable horizon of communal activity. Thus, life-world is "nothing but the historical world." ${ }^{31}$ Without this belonging in a community and a common world, all talk about historical experience remains abstract.

29 Husserl, The Crisis of European Sciences, 461.

3o Husserl, Zur Phänomenologie der Intersubjektivität 2. Teil, 623-624. See also Husserl, Zur Phänomenologie der Intersubjektivität 2. Teil, 228; Husserl, Zur Phänomenologie der Intersubjektivität 3. Teil, 214.

31 Husserl, Die Krisis der europäischen Wissenschaften, Ergänzungsbd., 426. 
Birth and death are issues that usually fall outside the scope of Husserlian phenomenology. The alleged dismissal of human finitude has been one of the major weaknesses of Husserl's project — an accusation that can be traced back to the first overviews of Husserl's phenomenological project, such as Levinas's 1940 essay "The Work of Edmund Husserl." 32 These conceptions rely often on the view that Husserl, while recognizing the unquestioned finitude of human existence, had to exclude the topics of birth and death from the field of the transcendental. As Husserl put it in his analyses on passive synthesis: "Transcendental life and the transcendental ego cannot be born; only the human being in the world can be born"33 - the transcendental ego stands always between the horizons of past and future, of retentional and protentional awareness, without which no idea of consciousness would be conceivable. Consequently, we can imagine neither its inception nor cessation in a strictly phenomenological sense, for the givenness of birth and death would of course presume the intentional flow of a transcendental ego to which they are given. Thus mortality, according to this view, stands as the final gatekeeper between the transcendental ego and the empirical person.

With regard to the topic of finitude, however, we should acknowledge a certain shift of position in Husserl's thinking. From the beginning of the 1930s, Husserl came to realize that both birth and death do indeed connote a certain transcendental significance, that is, they both have an essential role in the process of world-constitution. They do so, however, not as occurrences within experience - death cannot be intuitively experienced — but as a kind of horizontal structure delimiting the span of our lives within a socio-historical, generative context. ${ }^{34}$ In the Cartesian Meditations, Husserl referred to the "genetic problems of birth and death and the generative nexus of psychophysical being" as belonging to a "higher level" of investigation, presupposing "a tremendous labor of explication pertaining to the lower spheres." ${ }^{35}$ It is particularly through

32 Emmanuel Levinas, "The Work of Edmund Husserl," in Discovering Existence with Husserl, ed. Richard A. Cohen and Michael B. Smith (Evanston, IL: Northwestern University Press, 1988), 75 .

"[...] transzendentale Ich, nicht das empirische Welt-Ich, das sehr wohl sterben kann" (Husserl, Analyses Concerning Passive and Active Synthesis, 428-469 [Analysen zur passiven Synthesis, 379]).

34 On birth and death as limit-phenomena, see Steinbock, "Husserl's Static and Genetic Phenomenology," 305ff.

35 "Nur daß damit freilich noch die oben bezeichneten generativen Probleme von Geburt und Tod und Generationszusammenhang der Animalität nicht berührt sind, die offenbar 
the dimension of intersubjective generativity that birth and death have any significance for me as transcendental categories. It is not until I grow into the idea of historical community that this horizontal structure of finitude is realized. ${ }^{36}$ I grow into my own mortality through others - without this intersubjective dimension, the transcendental significance of finitude falls short.

Thus, from the perspective of phenomenological theory of the subject, the topic of generativity entails a significant distention of the scope of meaningconstitution. Alongside the forms of meaning-constitution that have their origin in the conscious life of the individual, Husserl discussed those forms of meaning and sense that have their genuine origin outside of the activity of the individual ego. These forms, rather than being actively instituted through particular Urstiftungen, are essentially "appropriated" (übernehmen, aufnehmen). This means that they involve an element of asymmetry and partiality in regard to the original institution of sense-an asymmetry that originates from our mortality and finitude. ${ }^{37}$ But it is exactly this partiality that endows the human traditions their unique character as something "passed forward."

To put it in simpler terms, what the dimension of generativity opened up was the idea of inheritance as the essential condition of human existence. ${ }^{38}$ Becoming a part of a human community that transcends my finite being means that we are swept into this complex process of tradition precisely in the form of "passing forward" (Lat. tradere) of sense: we find ourselves in a specific historical situation defined by a nexus of cultural objectivities and practices, a certain socio-symbolic order and political institutions. The whole idea of inheritance means that as finite beings, we are never fully on our own but necessarily forced to carry the weight of the past. The inherited sense and meaning is never given to us in full intuitive evidence; we are in touch with signs and symbols whose world has permanently deceased, we are addressed by narratives that have been handed down to us. Thus, as Husserl states in a late manuscript: "The development of the future is the task of the living, but the future

einer höheren Dimension angehören und eine so ungeheure auslegende Arbeit der unteren Sphären voraussetzen, daß sie noch lange nicht zu Arbeitsproblemen werden können" (Husserl, Cartesian Meditations, 142 [Cartesianische Meditationen, 169]).

36 Husserl, Zur Phänomenologie der Intersubjektivität 3. Teil, 140. On Husserl's critique of Heidegger's concept of death, see Husserl, Die Krisis der europäischen Wissenschaften, Ergänzungsbd., 332.

37 See especially Husserl, Zur Phänomenologie der Intersubjektivität 2. Teil, 222; Husserl, Ideas Pertaining to a Pure Phenomenology 2. Book, 126 (Ideen zu einer reinen Phänomenologie, 119). Cf. Anthony Steinbock, Home and Beyond: Generative Phenomenology after Husserl (Evanston, IL: Northwestern University Press, 1995), 196.

38 See Husserl, Die Krisis der europäischen Wissenschaften, Ergänzungsbd., 51. 
is realized only through a permanent form of activity, which has the character of reawakenment of the spirit of the deceased [...]."39 In other words, since our embeddedness in a world of sense is dependent on the process of origination, the only way of bringing this condition to light is to engage in a conversation with the past.

Seen from this communal perspective, historical experience is more than a reactivation of the past. It is also a practical idea that realizes itself in the continuation of a tradition, in the process of taking up previous accomplishments and forming a relation to them. This relation can, of course, be simply affirmative, or it can also be a critical one. A membership in a scientific community, for instance, is a matter of both: it means that one learns from and builds on previous theories and concepts and forms a critical relation to them. As in the case of science, a critique of the past is actually one of the central practices through which the individual participates in the unified tradition of this community.

\section{5}

\section{Conclusion}

In this essay, I have discussed the idea of historical experience in the context of Husserlian phenomenology. I argued that on the basis of Husserl's analysis, the experience of history is basically defined by three central conditions: teleology, communality and finitude. First, I showed that the idea of teleology was to be seen as one of the central conditions of historical experience. It was exactly the concept of teleology, rather than temporality, which opened up the question of duration in experience and formed the basis for genuinely historical experience. Instead of being defined by complete transparency, Husserl defined this type of experience in terms of activation and reactivation, of forgetting and remembering. Secondly, I argued for the constitutive significance of communality as the basic generative horizon through which the historical transmittance of sense takes place. By doing so, historical experience was seen in connection to the general idea of the life-world without which all talk about historical experience remains unfounded. Lastly, I highlighted the role of human finitude as a central condition for the experience of history. It was exactly Husserl's late phenomenology of generativity that was able to fully reconcile

39 "Die Entwicklung der Zukunft ist Sache der Lebenden, ihre Fortbildung ist es, die Zukunft schafft. Aber die Zukunft wird durch eine ständige Aktivität, die den Charakter einer Wiederverlebendigung des Geistes der Verstorbenen hat [...]" (Husserl, Die Krisis der europäischen Wissenschaften, 489). 
with this experience of finitude. We are historical beings because we recognize our own finitude and the fact that the world will go on existing without us.

This extended view on the historical character of experience had important consequences not only for Husserl's phenomenological theory of subjectivity but also for his ethics of the human person. As Husserl began to emphasize during the 1920s, without taking into account the temporally developing character of the human person all ethical considerations are doomed to remain abstract. Ethical and moral reflection, rather than being a Kantian rule-oriented process, should be understood as a fundamentally critical praxis that realizes itself on the basis of our own, acquired capabilities and our embeddedness in a historical situation. What we should do and aspire to accomplish is always relative to concrete possibilities. Renewal (Erneuerung), both personal as well as communal, is the ultimate aim of all genuine ethics. ${ }^{40}$

What history does, quite concretely, is provide the necessary tools for the execution of this type of reflection. Historical reflection, besides being a study of the past, is a way to uncover our own historical presuppositions and to increase understanding of ourselves. Phenomenology, as a science of the experience and the world, cannot execute its task without taking into account the historical descending of both experience and its correlate, the life-world.

$40 \quad$ Edmund Husserl, Aufsätze und Vorträge (1922-1937) (Dordrecht: Kluwer, 1989), 57ff. 